\title{
Kombinasi Geolistrik Dan Grid Sampling Untuk Mengidentifikasi Adanya Kontaminasi Hydrocarbon Pada Tanah
}

\author{
Supriyadi \\ Fakultas Teknik, Program Studi Teknik Mesin \\ Universitas Soerjo Ngawi
}

Received : 30-12-2020

Reviewed : 30-12-2020

Online Published : 31-12-2020

\begin{abstract}
Abstrak
Hydrocarbon pada permukaan tanah dapat dilihat secara visual namun hal ini tidak dapat menghasilkan nilai kuantitatif dan kualitatif yang akurat dalam menentukan berapa jumlah volume dari tanah yang terkontaminasi tersebut. Oleh karena itu dibutuhkan studi yang dapat menjelaskan secara kuantitatif dan kualitatif pada tanah terkontaminasi sehingga memudahkan dalam penanganan dan pengelolaannya.

Geolistrik merupakan salah satu metode kuantitatif yang dapat digunakan dalam menentukan kondisi permukaan tanah. Secara kualitatif, komposisi tanah dapat dibuktikan dengan sampling laboratorium untuk menentukan apakah termasuk ke dalam kategori limbah bahan berbahaya dan beracun (LB3) atau tidak sesuai dengan lampiran V yang terdapat pada Peraturan Pemerintah No.101 tahun 2014. Studi ini fokus pada tahapan untuk mengidentifikasi adanya hydrocarbon pada tanah menggunakan kombinasi geolistrik dan grid sampling sehingga mendapatkan volume yang lebih akurat besaran tanah terindikasi mengalami kontaminasi. Sedangkan batasan studi ini adalah dilakukan pada bekas fasilitas B-mediasi yang diduga terkontaminasi. Berdasarkan studi geolistrik yang telah dilakukan, volume permukaan tanah yang diduga terkontaminasi diperoleh sebesar $689 \mathrm{~m} 3$ (setara 1.381 ton). Sementara ketika menggunakan kombinasi data geolistrik dan grid sampling pada area diduga tersebut, didapat volume yang terindikasi terkontaminasi sebesar 594 m3 (setara 1.190 ton). Hasil ini dapat disimpulkan bahwa dengan menggunakan kombinasi metode geolistrik dan grid sampling dalam mengidentifikasi adanya kontaminasi pada permukaan tanah dapat menjelaskan secara kuantitatif dan kualitatif volume tanah yang terkontaminasi dengan keakuratan sebesar $115 \%$.
\end{abstract}

Kata kunci : Hydrocarbon; Tanah Terkontaminasi; Geolistrik; Grid Sampling.

\section{Pendahuluan}

PT XXX merupakan perusahaan Migas yang beroperasi aktif di area Provinsi Kalimantan. Beberapa aktivitas kegiatan operasional secara rutin dilaksanakan antara lain adanya aktivitas pemboran, pembersihan tangki maupun aktivitas lainnya yang dapat menghasilkan sisa produksi berupa limbah bahan berbahaya dan beracun (LB3) yang mengandung hydrocarbon dimana bahan tersebut harus dilakukan pengelolaan sesuai dengan tata cara pengelolaan limbah.

Perusahaan sebelumnya menggunakan metode Bmediasi dalam pengelolaan limbah B3, akan tetapi fasilitas tersebut saat ini sudah tidak digunakan kembali dan akan dilakukan pemulihan. Bioremediasi merupakan metode yang digunakan untuk pengelolaan LB3 dengan menambahkan mikroba pada oil sludge sehingga kadar limbah B3 / hydrocarbon dapat menurun hingga memenuhi baku mutu lingkungan. Untuk memenuhi peraturan perundang undangan lingkungan hidup terhadap bekas fasilitas Bmediasi tersebut mengharuskan untuk dilakukan identifikasi terhadap permukaan tanah eksisting baik kuantitatif maupun kualitatif dan membuat rencana penanganan dan pengelolaan lokasi terindikasi tanah terkontaminasi. Pada tahap awal terlebih dahulu membuat Rencana Pemulihan Lahan Terkontaminasi (RPLT). Dalam penyusunan RPLT yang mengacu pada Permen LH No.33 tahun 2009 tentang tata cara pemulihan lahan terkontaminasi LB3 terdapat kendala terkait dengan penentuan volume lahan terkontaminasi. Pada Permen LH No.33 tahun 2009, tidak mengatur secara spesifik bagaimana cara menentukan volume yang akurat mengenai tanah yang terkontaminasi salah satunya adalah dengan adanya kontaminasi bahan hydrocarbon.

\section{Metodologi}

Geolistrik merupakan salah satu salah satu pengukuran metode geofisika dengan cara menggunakan arus listrik yang dialirkan melewati media lapisan tanah untuk mendapatkan nilai resistivitas (tahanan) dari permukaan lapisan tanah. Geolistrik yang dilaksanakan menggunakan konfigurasi Schlumberger.

Ruang lingkup geolistrik yang dilakukan terbatas pada beberapa aspek yaitu pemboran inti dan interpretasi hasil coring, akuisisi lintasan geolistrik dan interpretasi geofisika dan kalibrasi hasil coring dengan penampang geolistrik resistivitas. Hasil dari pembacaan geolistrik, dapat dilakukan perhitungan volumetrik untuk mengetahui jumlah tanah terindikasi terkontaminasi pada setiap lokasi. Metode perhitungan yang digunakan dengan menghitung peta sebaran (isopach) dari penampang geolistrik yang sudah dikalibrasi dengan data pemboran inti. 


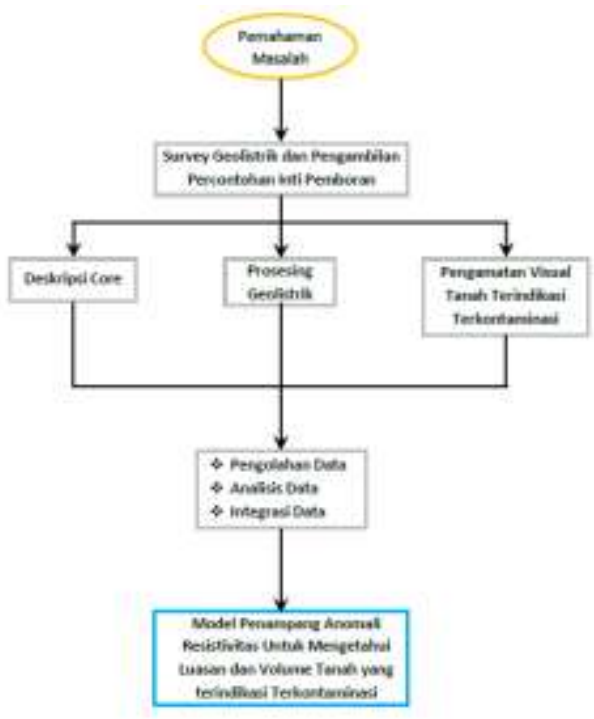

Gambar 1. Diagram alir dari tahapan kegiatan geolistrik

Interpretasi geolistrik untuk mengindikasikan lahan terkontaminasi mengunakan hasil resistivity dalam satuan Ohm meter yang terbaca di alat ukur. Resistivity terukur ini diterjemahkan dalam bentuk warna, untuk warna merah mengindikasikan adanya hidrokarbon.

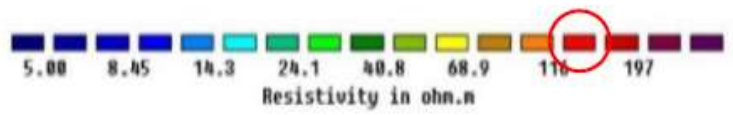

Gambar 2. Acuan nilai resistivity dalam satuan Ohm meter (lingkaran merah, terindikasi adanya hidrokarbon).

Dari hasil geolistrik selanjutnya dilakukan penentuan area terkontaminasi yang terdiri dari penetapan sebaran kontaminan, kondisi fisik lahan, pola pergerakan air tanah, curah hujan dan sampling dengan metode grid. Metode grid berupa garis dengan bidang ruas area yang bervariasi.

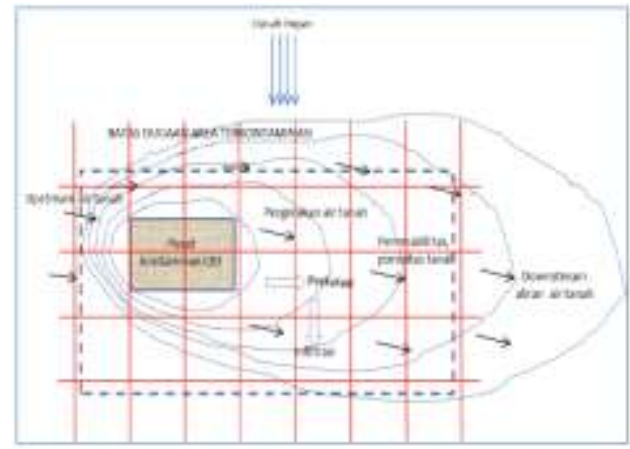

Gambar 3. Metode grid area untuk penentuan lokasi sampling pada penentuan area terkontaminasi.

Pada masing-masing lokasi yang diduga terkontaminasi limbah B3 / hydrocarbon contaminant yang diperoleh dari hasil geolistrik, maka dibuat grid untuk menentukan luasan yang akan diambil sampelnya. Titik sampel ditentukan pada pusat luasan antar grid (grid area), dikompositkan dengan 3 sampai 5 titik sampel tanah di dalam grid area. Setelah diperoleh hasil uji, maka dapat ditemukan sebaran luasan yang terkontaminasi limbah B3. Dengan sistem grid area dan komposit secara horizontal maka dapat diketahui status kontaminasi tanah tersebut per-luasan grid area. Untuk mendapatkan kedalaman dari area tersebut, juga dilakukan sampling secara komposit pada setiap kedalaman $30-50 \mathrm{~cm}$ hingga kedalam total mencapai $150 \mathrm{~cm}$ atau sesuai dengan kedalaman dari hasil bacaan geolistrik yang menyatakan terdapat indikasi terkontaminasi hydrocarbon.

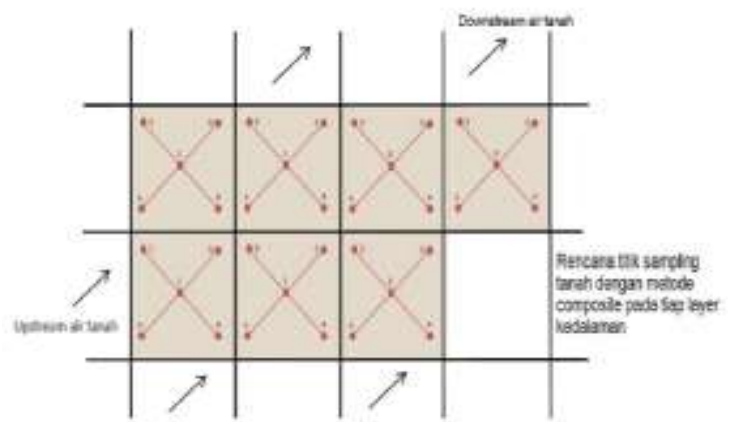

Gambar 4. Metode penentuan titik sampling pada setiap grid area yang terindikasi terkontaminasi.

Sampling yang telah didapat kemudian selanjutnya dilakukan pengujian laboratorium yang terakreditasi dengan mengacu kepada baku mutu yang terdapat pada Peraturan Pemerintah No.101 tahun 2014 tentang pengelolaan limbah bahan berbahaya dan beracun lampiran V. Untuk area dan layer yang melebihi dari baku mutu yang terdapat pada lampiran $\mathrm{V}$ pada peraturan tersebut, maka area tersebut dapat disimpulkan area dan lapisan yang terkontaminasi dimana selanjutnya disebut sebagai volume tanah terkontaminasi yang harus dikelola.

\section{Hasil dan Pembahasan}

Geolistrik dilakukan menggunakan beberapa lintasan pada setiap lintasan lokasi bekas fasilitas B-mediasi. Contoh hasil lintasan dapat dilihat dari gambar berikut :

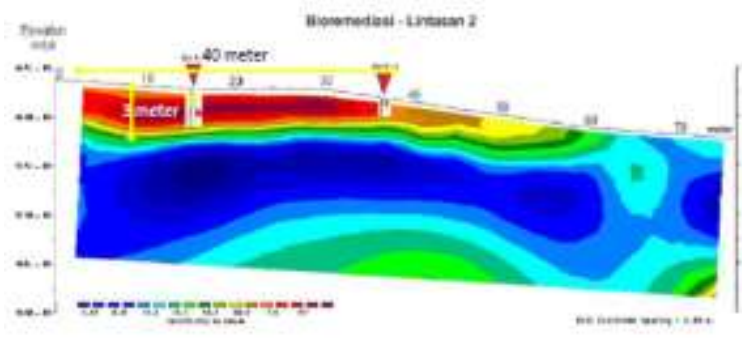

Gambar 5. Hasil resistivity indikasi hydrocarbon dalam tampilan panjang dan kedalaman pada lintasan 2 lokasi bekas fasilitas Bmediasi.

Dari hasil geolistrik, didapat hasil perhitungan volumetrik pada setiap lokasi tanah terkontaminasi dengan hasil sebagai seperti tabel berikut : 
Tabel 1. Hasil Perhitungan Volumetrik Metode Geolistrik

\begin{tabular}{lcc}
\hline \multicolumn{1}{c}{ Lokasi } & $\begin{array}{c}\text { Estimasi } \\
\text { volume } \\
(\mathrm{m} 3)\end{array}$ & $\begin{array}{c}\text { Estimasi } \\
\text { Tonase } \\
\text { (ton) }\end{array}$ \\
\hline Bekas Fasilitas B-mediasi & 689 & 1.381 \\
Total Tanah Terkontaminasi & 689 & 1.381
\end{tabular}

Hasil penampang dan sebaran area tanah terkontaminasi yang didapat dari hasil geolistrik, selanjutnya dibuatkan grid area pada setiap area yang terindikasi terkontaminasi dari hasil geolistrik.

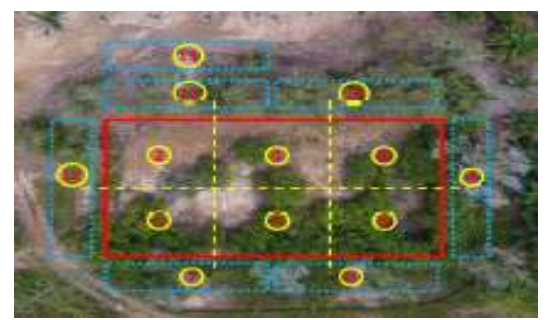

Gambar 6. Pola grid area sebagai acuan titik sampling pada area bekas fasilitas B-mediasi.

Setelah dilakukan analisa laboratorium pada grid sampling, maka diperoleh grid area dan layer grid yang melebihi parameter baku mutu sesuai dengan peraturan pemerintah No. 101 tahun 2014 lampiran V. Selanjutnya hasil tersebut digunakan dalam menentukan volume area terkontaminasi limbah B3 / Hydrocarbon Contaminant seperti pada tabel berikut:

Tabel 2. Volume Hydrocarbon Contaminant pada Bekas Fasilitas B-Mediasi

\begin{tabular}{ccccc}
\hline $\begin{array}{c}\text { Grid } \\
\text { Area }\end{array}$ & $\begin{array}{c}\text { Dimensi } \\
(\mathrm{P} \times \mathrm{L}) \\
(\mathrm{m})\end{array}$ & $\begin{array}{c}\text { Luas } \\
(\mathrm{m} 2)\end{array}$ & $\begin{array}{c}\text { Layer } \\
\text { Kedalaman } \\
\text { volume }(\mathrm{m})\end{array}$ & $\begin{array}{c}\text { Volume } \\
(\mathrm{m} 3)\end{array}$ \\
\hline $\begin{array}{c}\text { (2) } \\
\text { BRM } \\
(4)\end{array}$ & $15 \times 11$ & 165 & 1.0 & 165 \\
$\begin{array}{c}\text { BRM } \\
(6)\end{array}$ & $15 \times 11$ & 165 & 1.5 & 247.5 \\
$\begin{array}{c}\text { BRM } \\
(11)\end{array}$ & $165 \times 3$ & 66 & 1.5 & 82,5 \\
$\begin{array}{c}\text { BRM } \\
\text { Total Tanah Terkontaminasi di Bekas } \\
\text { Fasilitas B-mediasi }\end{array}$ & 594 \\
\multicolumn{5}{c}{} \\
\end{tabular}

Volume tanah terkontaminasi sebesar $594 \mathrm{~m} 3$ ini dijadikan sebagai acuan dalam penanganan dan pengelolaan tahap awal. Realisasi pelaksanaan pengelolaan di lapangan harus benar benar dilakukan pengawasan sehingga volume tanah terkontaminasi yang dikelola sesuai dengan yang direncanakan dan tidak terlampau jauh perbedaannya.

\section{Simpulan}

Berdasarkan studi geolistrik yang telah dilakukan, volume tanah yang diduga terkontaminasi hydrocarbon diperoleh sebesar $689 \mathrm{~m} 3$ (setara 1.381 ton). Setelah dilakukan pengembangan dengan menggunakan kombinasi data geolistrik dan grid sampling pada area diduga tersebut, didapat volume yang terindikasi terkontaminasi sebesar 594 m3 (setara 1.190 ton). Dari hasil ini dapat disimpulkan bahwa dengan mengkombinasi metode geolistrik dan grid sampling dapat menjelaskan secara kuantitatif dan kualitatif volume tanah yang terkontaminasi hydrocarbon mendapatkan keakuratan sebesar $115 \%$.

Dengan prosentase keberhasilan $115 \%$ metode penentuan volume tanah terkontaminasi melalui geolistrik dan grid sampling dapat digunakan pada lokasi lain dengan mempertimbangkan efektifitas dan keekonomian. Adapun sebagai pembanding dengan hasil yang disampaikan dalam jurnal ini diperlukan data - data tambahan yang memberikan informasi mengenai realisasi pelaksanaan pengelolaan tanah terkontaminasi yang dibutuhkan sebagai bahan verifikasi lebih lanjut terhadap metode kombinasi yang telah dipilih (geolistrik dan grid sampling).

\section{Daftar Pustaka}

E. A. Atakpo, 2013. Resistivity Imaging of Crude Oil Spill in Ogulaha Coastal Cummunity. Brutu, L.G.A, Delta State, Nigeria, Department of Physics, Delta State University, Abraka, Nigeria.

Waluyo, 2001. Panduan Workshop Eksplorasi Geofisika (Teori \& Aplikasi) Metode Resistivitas. Laboratorium Geofisika, Fakultas MIPA, UGM, Jogjakarta.

Brown, G. H., N. I. Fisher, 1972. Subsampling a mixture of sampled materials", Technometric 14: 663-668.

Brus, D. J., L. E. E. M. Spätjens, J. J. de Gruijter, 1999. A sampling scheme for estimating the mean extractable phosphorous concentration of fields for environmental regulation", Geoderma 89: 129-148. 